\title{
パントテン酸カルシウムが食品の味に及ぼす影響 The Influence of the Addition of Calcium Pantothenate upon the Taste of Fuods
}

(昭和 40 年 1 月 8 日受理)

石田欽一横尾良夫
(Kinichi Ishida)
小 (Yoshio Yokoo)
(Yoshito Koyama)

The change of taste by calcium pantothenate enrichment on foods was examined.

To the liquid luxurious foods, which are obtainable in the open market and the simple taste sub. stances, calcium pantothenate was added, and their tastes were judged mainly by Scheffés paired com. parison method modified by Ura.

The results were as follows:

(1) In the case of simple taste substances, the addition of the calcium pantothenate weakened the bitterness of caffeine and soluble saccharine, and, therefore, this gave a pleasant influence on the taste.

(2) In the case of liquid luxurious foods, the taste of orange juice and wine was remarkably im. proved. It is possible to conclude that the addition of calcium pantothenate is recommendable.

近年食品に強化されるビタミン類はその油溶性, 水溶 性をとわずかなりの数にのぼっている。このなかでパン トテン酸塩を強化した製品はチューインガム, 乳酸菌飲 料, ミルク類, などにみられ，また，ハントテン酸の慨 品への強化については, 山口ら”, はハントテン酸カル シウムをオレンジジュース，アイスクリームに強化した ときの製品に及ぼす影響，安定性などについて，また大 武 ${ }^{2)}$ は肉製品の性質に及ぼす影篦について，それぞれ報 告している。

ビタミン類を食品に強化する場合, そのものの安定性 の問題も重要であるが, 食品である以上強化することに よって官能的な要素が悪くなってはならないわけで, 現 状維持か, できれば未添加のものよりも良くなることが 望ましい。

今まで強化されたビタミン類はそのほとんどがこの要 求を満たしているようであるが中にはビタミン $\mathrm{B}_{1}$ のあ る誘導体を粉末ジュースに強化した場合, 誘導体自身の 味が商品価值を減じたり，またキャンデー類にビタミン $\mathrm{B}_{1}, \mathrm{~B}_{2}$ などを強化した場合，特有の味，臭いのため，製 品の種類が限定される，などの好ましくない例もある。

パントテン酸またはその塩類を食品に強化した場合の 味に及ぼす影響についてはまだ報告がないようである。

現在これらのなかで食品添加物として許可されている
のはパントテン酸のナトリウム塩 $\left(\mathrm{C}_{8} \mathrm{H}_{16} \mathrm{O}_{5} \mathrm{NNa}\right)$ とカ ルシウム塩 $\left(\left[\mathrm{C}_{9} \mathrm{H}_{16} \mathrm{O}_{5} \mathrm{~N}\right]_{2} \mathrm{Ca}\right)$ だけである。

著者らはこの5ちパントテン酸カルシウムを用い,こ れが単一の呈味物質に及ぼす影響について調べ，またど のような倉品が味に影響を受けるかということについて 数種の市販液状咾好佔品に添加して, 味扰よび咾好度に ついて官能審查を実施したので報告する。

\section{実 験方 法}

\section{1. 実験材料}

1）パントテン酸カルシウム：富士薬品工莱 $\mathrm{K} \mathrm{K}$ 製, 食品添加物用, 粉木パントテン酸カルシウム（以下 $\mathrm{PaA}$ -Ca と略）の10\%溶液を調整し，この溶液の規定量を試 料に溶かす方法をとった。

2）試料扣よび $\mathrm{PaA}-\mathrm{Ca}$ 添加量：第 1 表の試料を用い た。PaA-Ca はほとんどの武料に対して $0.01 \% ， 0.02$ \%添加した。また表中, 試料湍度が 100 とあるのは, 試 料を稀釈せず，とのまま用いたことを示与。

2. 官能賽查

1) 手法：官能䆺查に用いた手法は主として, Scheffé の対比較法浦氏改变法（以下対比較法と略）を用い，そ の他 Duo-trio test, Triangle test も用いた。

2) パネル：愛知紧飭品工業試験所・職員。 
栄養と食 糧

第 1 表 試料および $\mathrm{PaA}-\mathrm{Ca}$ 添加量

\begin{tabular}{|c|c|c|c|c|c|c|c|}
\hline & \multirow{2}{*}{ 試 } & \multirow{2}{*}{$\mid \begin{array}{c}\mid \begin{array}{c}\mid \\
(\%)\end{array} \\
(\%)\end{array}$} & \multicolumn{3}{|c|}{$\mathrm{PaA}-\mathrm{Ca}$ 添加量 $(\%)$} & \multirow{2}{*}{$-\left|\begin{array}{c}\text { 試料温度 } \\
\left({ }^{\circ} \mathrm{C}\right)\end{array}\right|$} & \multirow{2}{*}{ 備 } \\
\hline & & & 対照 & No. 1 & No. 2 & & \\
\hline \multirow{3}{*}{ 単 } & ク エ ン 酸 & 0.3 & 0 & 0.01 & 0.02 & 16 & 試薬 1 級品 \\
\hline & 石酸 & 0.3 & 0 & 0.01 & 0.02 & 16 & 試薬 1 級品 \\
\hline & サッカリンナトリウム & 0.025 & 0 & 0.01 & 0.02 & 16 & 食品添加物 \\
\hline \multirow{5}{*}{$\begin{array}{l}\text { 呈 } \\
\text { 味 } \\
\text { 物 } \\
\text { 質 }\end{array}$} & ブ ド ウ 糖 & 13. 0 & 0 & 0.01 & - & 16 & 含水結晶ブドウ糖 水分 $8.80 \%$ \\
\hline & カリウム明ばん & 0.1 & 0 & 0.01 & 0.02 & 16 & 試薬 1 級品 \\
\hline & カフェイン & 0.15 & 0 & 0.01 & - & 16 & 水分 $3.42 \%$ \\
\hline & 食 & 1.0 & 0 & 0.01 & 0.02 & 16 & 試薬特級品 \\
\hline & $\begin{array}{l}\text { グルタミン酸ナトリウ } \\
\text { ム }\end{array}$ & 0.3 & 0 & 0.01 & - & 16 & $\begin{array}{l}\text { 食品添加物, 食塩を } 0.15 \% \text { 添加し } \\
\text { て使用 }\end{array}$ \\
\hline \multirow{6}{*}{ 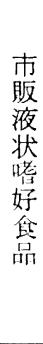 } & トマトジュース & 100 & 0 & 0.04 & 0.1 & 12 & 直糖 $3.79 \%$ 蔗糖 $0.05 \% *$ \\
\hline & $\begin{array}{c}\text { オン ジジュース } \\
\text { (濃 }\end{array}$ & 20 & 0 & 0.01 & 0.02 & 11 & 直糖 $61.87 \%$ 蔴糖 $14.25 \%$ * \\
\hline & 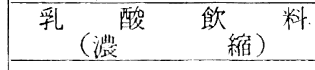 & 20 & 0 & 0.01 & 0.02 & 11 & 直糖 $30.39 \%$ 蔗糖 $30.54 \%$ * \\
\hline & $\exists(\text { インスタンド })^{-}$ & 3 & 0 & 0.01 & 0.02 & 60 & 水分 $3.15 \%$, 砂糖 $10 \%$ 添夰儿て使用 \\
\hline & $\begin{array}{l}\text { コ } \\
\text { (加糖, インスタント) }\end{array}$ & 15 & 0 & 0.02 & - & 60 & 蕉糖 $39.66 \%$ \\
\hline & گ゙ દ゙ & 100 & 0 & 0.02 & - & 13 & $\begin{array}{l}\text { 比雷0.992 アルコール分 } 13.0 \% \text { ア* } \\
\text { エキス分 } 2.4 \% \text { 総酸7. } 4\end{array}$ \\
\hline
\end{tabular}

第 2 表 クエン酸, 酒石酸の官能審査結果扰よび $\mathrm{pH}$

\begin{tabular}{|c|c|c|c|c|c|c|}
\hline \multirow[t]{2}{*}{$\mathrm{P}_{2}$ 試 料 } & ク & ン & 酸 & 酒 & 石 & 酸 \\
\hline & 対 & No. 1 & No. 2 & 照 & No. 1 & No. 2 \\
\hline $\mathrm{PaA}-\mathrm{Ca}$ 添加量 $(\%)$ & 0 & 0.01 & 0.02 & 0 & 0.01 & 0.02 \\
\hline $\mathrm{pH}$ & 2.51 & 2.55 & 2.56 & 2.43 & 2. 46 & 2. 48 \\
\hline 定酸 & 3.99 & 3.99 & 3. 99 & 4. 42 & 4. 42 & 4.42 \\
\hline 平均踖 好度 & -0.071 & 0.095 & -0.024 & 0.028 & 0.028 & -0.056 \\
\hline
\end{tabular}

同上分散分析表
(クエン 酸)
（酒 石 酸）

\begin{tabular}{|c|c|c|c|c|c|}
\hline 要 & 因 & 平方和 & 自由度 & 平均平方 & 分散 比 \\
\hline 主 & 加 & 0.69 & 2 & \multirow{7}{*}{$\begin{array}{l}0.35 \\
0.67 \\
6.54 \\
0.02 \\
0.22 \\
1.82\end{array}$} & \multirow{7}{*}{$\begin{array}{l}\mathrm{F}^{1}{ }_{20}(\alpha= \\
0.10) \\
\quad=2.97\end{array}$} \\
\hline & 固人 & 8.04 & 12 & & \\
\hline & せ & 6. 54 & 1 & & \\
\hline & 序 & 0.02 & 1 & & \\
\hline & 固人 & 1. 31 & 6 & & \\
\hline 䛊 & 差 & 36.40 & 20 & & \\
\hline & 体 & 53.00 & 42 & & \\
\hline
\end{tabular}

\begin{tabular}{|c|c|c|c|c|}
\hline 因 & 平方和 & 自由度 & 平均平方| & 分散 比 \\
\hline 効 & 0.17 & 2 & 0.09 & \\
\hline 主効 $\times$ 個人 & 16.50 & 10 & 1. 65 & 1. 38 \\
\hline 組 合 せ & 0 & 1 & 0 & \\
\hline 序 & 0.5 & 1 & 0.5 & \\
\hline 順序 $\times$ 個人 & 2.5 & 5 & 0.5 & \\
\hline 差 & 30.33 & 17 & 1.2 & \\
\hline 全 & 50.00 & 36 & & \\
\hline
\end{tabular}




\section{実験結果および考察}

\section{1. 单一呈味物質}

1）酸味物質（クエン酸，酒不酸）

結果を第 2 表に示す。 $\mathrm{pH}$ はクエン酸, 酒石酸共に $\mathrm{PaA}-\mathrm{Ca}$ の添加量が堌すに従いわずかに高くなるが，滴 定酸度には变化がみらられなった。官能寒査はクエン酸 はパル7名で, 酒石酸はパネル6名で共に対比較法に よって刺激の强弱について夷施したが，主效には有意差 がみられ歹，クェン酸におい・て組合わせ約果に10\%の危 除率で有憲学がスられた。

2）【味物筫（サッカリンナトリウ之，ブドウ糖）

サッカリンナトリウム，ブドゥ糖共に $\mathrm{PaA}-\mathrm{Ca}$ の添 加によって pH の変化が双られた（第 3 表）。官能審査 はブドゥ糖はパネル 7 名で Duotrio testによって調べ たぶ有U性によられなかった。サッカリンナトリウムは パネル8名し対比較法により実施した。結果としてほぼ

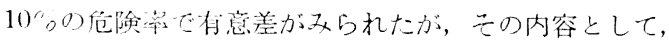
サッカリンり持つ苫昧が $\mathrm{PaA}-\mathrm{Ca}$ の添版によって弱く なることがかかた。

第3 表サッカリンナトリウ之,ブドウ糖の官 能審査結果扰よび $\mathrm{pH}$

\begin{tabular}{|c|c|c|c|c|c|c|}
\hline & \multicolumn{3}{|c|}{ サッカリンナトリウム } & \multicolumn{2}{|c|}{ ブドウ糖 } \\
\hline & & 対 & 1 & 2 & 対照 & No. 1 \\
\hline & $\begin{array}{l}\text { 添加量 }(\%) \\
\mathrm{pH}\end{array}$ & $\begin{array}{r}0 \\
5.70\end{array}$ & $\begin{array}{l}0.01 \\
5.79\end{array}$ & $\begin{array}{l}0.02 \\
5.87\end{array}$ & $\left|\begin{array}{r}0 \\
5.42\end{array}\right|$ & 5.70 \\
\hline$\therefore$ 均 & 嗜 好度 & -0.354 & 0.292 & 0.062 & & \\
\hline
\end{tabular}

分散分析表（サッカリンナトリウム）

\begin{tabular}{|c|c|c|c|c|}
\hline 因 & 平方和 & 自由度 & 平均平方 & 分散 比 \\
\hline 主 & 10.29 & 2 & 5.15 & $2.52{ }_{0.10}^{\mathrm{F}^{2}{ }_{23}(\alpha=}$ \\
\hline 主効×侗人 & 16.04 & 14 & 1.15 & $=2.55$ \\
\hline 組 合世 & 0.33 & 1 & 0.33 & \\
\hline 順 & 0.08 & 1 & 0.08 & \\
\hline 順序 $\times$ 侗人 & 12.25 & 7 & 1.75 & \\
\hline 诏 & 47.01 & $2 ?$ & 2.11 .1 & \\
\hline 金 & 86.00 & 48 & & \\
\hline
\end{tabular}

刐定結果（ブドウ糖）

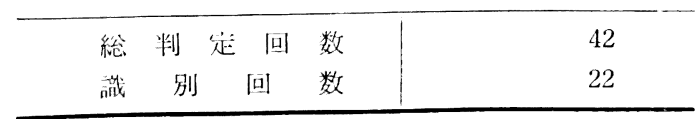

3）啮味および苦味物質（カリウム明ばん，カフェイ )

第 4 表に示すよ5にこの場合も $\mathrm{PaA}-\mathrm{Ca}$ を添加する ことによって $\mathrm{pH}$ が高くなっている。官能審査はカリウ
ム明ばんの場合はパネル 7 名で対比較法によって夷施し たが，主效に有意差が更られなかった。また順序效果が 主邻に比してかなり大きくなっているふ心,これは陚料が

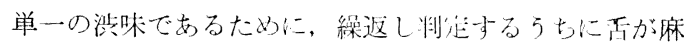
痺し, 差の判别を困難にしたためと䍐われる。カフェイ ンはパネル 7 名で Duo-trio testにより苦味の強弱につ いて来施した。この結果陚料间に5\%の危俛辛で有意差 があった。てして PaAーCa 老源加军るこ上によって苦

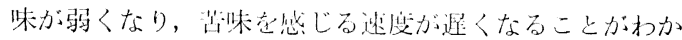
った。

第4衣 カフェイン，カリウム明ばんり官能塞 査結桨打よ0 $\mathrm{pH}$

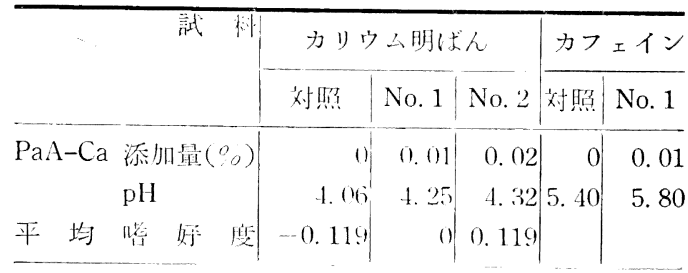

分青分析主（カリ山ム明ばん）

\begin{tabular}{|c|c|c|c|c|}
\hline 要 $\quad$ 列 & 平方和 & 自由形 & 平的平力 & 分散比 \\
\hline$i$ & 1. 19 & 2 & 0.60 & \\
\hline 立觔×润人 & 15.14 & 12 & 1. 26 & \\
\hline 組 合 世 & 0.38 & 1 & 1). 38 & $F^{1}$ \\
\hline 順 & 4.67 & 1 & 1. 67 & $2.020 .10)$ \\
\hline 順序入侗人 & 2.33 & 6 & 0.40 & $=2.91$ \\
\hline 钅: & 16.28 & 20 & 2.31 & \\
\hline 体 & 70.00 & 12 & & \\
\hline
\end{tabular}

判定結紧（カフェイン）

\begin{tabular}{|c|c|c|c|}
\hline 総 & 判 定 回 & 数 & 42 \\
\hline 識 & 別＼cjkstart回 & 数 & $28^{*}$ \\
\hline
\end{tabular}

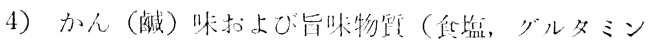
酸ナトリウム)

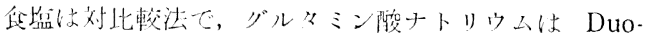

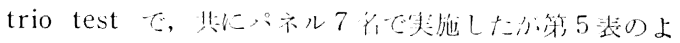

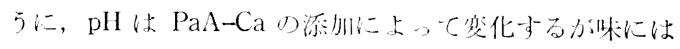

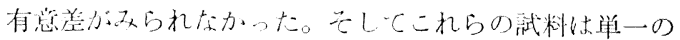

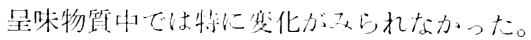

\section{2. 市服液状嫱好企监}

以上のよ5にカフェイン，サッカリンナトリウムに味 の变化が汉られたので，つぎに焦留に対しどのよ5な影

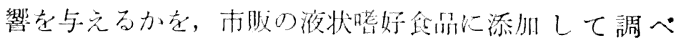
た。

1）トマトジュース扰じオレンジジュース 
第 5 表 食塩,グルタミン酸ナトリウムの官能 審査結果および $\mathrm{pH}$

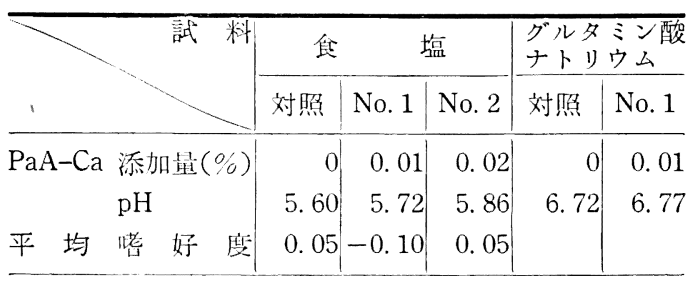

分散分析表（佔塩）

\begin{tabular}{lr|r|r|r|r}
\hline 要 因 & 平方和 & 自由度 & 平均平方 & 分散 比 \\
\hline 主 & 効 & 0.57 & 2 & 0.29 & \\
主効 $\times$ 個人 & 8.43 & 12 & 0.70 & \\
組 合 せ & 1.33 & 1 & 1.33 & \\
順 & 序 & 0.60 & 1 & 0.60 & \\
順序 X個人 & 1.90 & 6 & 0.32 & \\
誤 & 差 & 22.17 & 20 & 1.11 & \\
全 & 体 & 35.00 & 42 & & \\
\hline
\end{tabular}

判定結果（グルタミン酸ナトリウム）

\begin{tabular}{|c|c|c|c|}
\hline 総 & 判 定 回 & 数 & 42 \\
\hline 識 & 別回 & 数 & 17 \\
\hline
\end{tabular}

試験は PaA-Ca をトマトジュースには $0.1 \%, 0.04 \%$, オレンジジュースには $0.01 \% ， 0.02 \%$ ，それぞれ添加し た。

トマトジュースに打いては $\mathrm{pH}$ 打よび滴定酸度に变化 はみられなかった（第 6 表)。官能審査は共にパネル 9 名で対比較法により実施した。平均嗜好度は添加区の方 が良いという傾向がみられたが, トマトジュースに拉い ては試料間に有意差がなかった。一方オレンジジュース は主効には有意性がみられなかったが，主効メ個人の交 互作用に弱い有意性がみられた。このことは試料に対す るパネルの好みがまちまちであるためと思われるが，試 料間の味の差は添加区を好む理由として, 酸味, 渋味が 弱くなり，全体として味に丸味がでている。または，味 のバランスが良くなったことがあげられている。

第 6 表 トマトジュース, オレンジジュースの官能審査結果および $\mathrm{pH}$

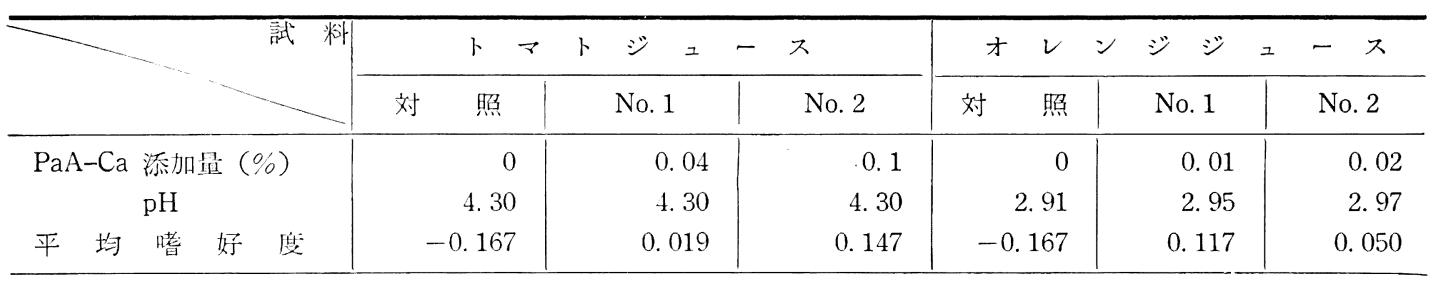

(トマトジュース)

\begin{tabular}{|c|c|c|c|c|}
\hline 要＼cjkstart因 & 平方和 & 自由度 & 平均平方 & 分 散 比 \\
\hline 主 & 2. 70 & 2 & 1. 35 & \multirow{7}{*}{$\begin{array}{r}3.79^{F^{1}{ }_{26}(\alpha=} \\
0.10) \\
=2.92\end{array}$} \\
\hline 主効×個人 & 17. 97 & 16 & 1. 12 & \\
\hline 組合也 & 4. 74 & 1 & 4. 74 & \\
\hline 順 & 0.67 & 1 & 0.67 & \\
\hline 順序 $\times$ 個人 & 3. 33 & 8 & 0.42 & \\
\hline 誤 & 32.59 & 26 & 1. 25 & \\
\hline 全 & 62.00 & 54 & & \\
\hline
\end{tabular}

2）乳酸领料およびローヒー

$\mathrm{PaA}-\mathrm{Ca}$ 添加による $\mathrm{pH}$ の翂化は乳酸飲料においてて られたが、コーヒーてて諗められなかった（第7表）。

官能審查はパネル 9 名で対比較法によって実施したが 共に有意性はみられなかった。

3）ココアおよびら゙どう酒

結果は第8 表のよ5に $\mathrm{pH}$ はココアにおいてはほとん ど変化しないが，ぶど5酒では0. 02\%添加することによ
(オレンジジュース)

\begin{tabular}{|c|c|c|c|c|}
\hline 因 & 平方和 & 自由度 & 平均平方 & 分散 比 \\
\hline 主 & 2.63 & 2 & 1.32 & 1. $38^{\mathrm{F}^{2}}{ }_{29}(\alpha=$ \\
\hline 是: 效以侗人 & 24.37 & 18 & 1. 35 & $\backslash \quad=1.45$ \\
\hline 維合世 & 0.27 & 1 & 0.27 & 1. $41_{0.25)}^{\mathrm{F}^{20}{ }^{29}(\alpha=}$ \\
\hline 順 & 0.60 & 1 & 0.60 & $=1.31$ \\
\hline 順序 $\times$ 個人 & 6.40 & 9 & 0.71 & \\
\hline 䛊 & 27.73 & 29 & 0.96 & \\
\hline 全 & 62.00 & 60 & & \\
\hline
\end{tabular}

って，0.1 変化した。また別に測定した滴定酸度には変 化が認められなかった。官能審査はココアはパネル6名 でぶどう酒はパネル7名で共に Triangle test で実 施した。ココアに拈ける識別テストでは試料間に有意差 がなかった。ぶどう酒に扰いては $1 \%$ の危険率で有意差 があった。

また暂好テストに扣いても $1 \%$ の危険率で有意差があ り添加区が好まれることがわかった。この場合パネルの 
第 17 巻 第 6 号

第 7 表 乳酸领料, コーヒーの官能審査結果および $\mathrm{pH}$

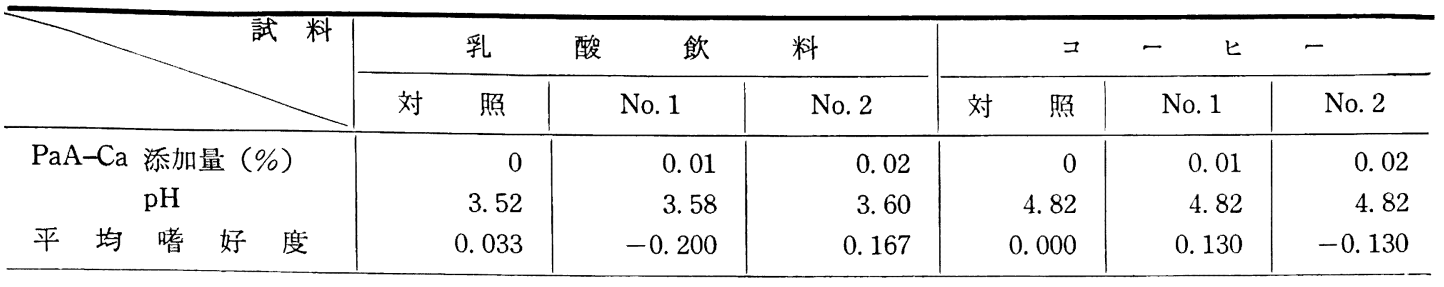

(乳 酸 飲 料)

\begin{tabular}{lr|r|r|r|c}
\hline \multicolumn{1}{l|}{ 要 } & 平方和 & 自由度 & 平均平方 & 分 散 比 \\
\hline 主 効 & 4.13 & 2 & 2.07 & 1.09 \\
主効 $\times$ 個人 & 16.87 & 18 & 0.94 & \\
組 合 せ & 1.67 & 1 & 1.67 & \\
順 & 序 & 0.27 & 1 & 0.27 & \\
順序 $\times$ 個人 & 2.06 & 9 & 0.23 & \\
誤 & 差 & 55.00 & 29 & 1.90 & \\
全 & 体 & 80.00 & 60 & & \\
\hline
\end{tabular}

第 8 表 ココアおよびぶどう酒の官能審査結 果および $\mathrm{pH}$

\begin{tabular}{|c|c|c|c|c|}
\hline & \multicolumn{2}{|c|}{$=\beth ア$} & \multicolumn{2}{|c|}{ ぶど 5 酒 } \\
\hline & 対照 & No. 1 & 対照 & No. 1 \\
\hline $\mathrm{PaA}-\mathrm{Ca}$ 添加量 $(\%)$ & 0 & 0.02 & 0 & 0.02 \\
\hline $\mathrm{pH}$ & 6.85 & 6.86 & 3. 75 & 3. 85 \\
\hline
\end{tabular}

ココア識別テスト

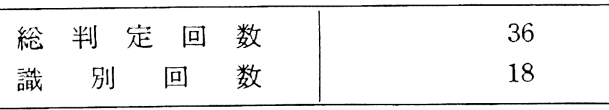

ぷど5酒識別テスト

\begin{tabular}{|c|c|}
\hline $\begin{array}{cccc}\text { 総 判 定 回 } & \text { 数 } \\
\text { 識 別 回 数 }\end{array}$ & $\begin{array}{l}21 \\
14^{*}\end{array}$ \\
\hline \multicolumn{2}{|c|}{ ぶど5酒嗜好テスト } \\
\hline $\begin{array}{l}\text { 総 判 定 回 数 } \\
\text { No.1を良とした回数 }\end{array}$ & $\begin{array}{l}14 \\
10^{*}\end{array}$ \\
\hline
\end{tabular}

* $1 \%$ 危険率で有意差あり

啫好度の判定には, 酸味, 苦味, 涉味などが基準となっ ていたか，PaA-Ca 添加試料はこれらの味が弱くなり， 全体として味がすっきりするために好まれたといらこと がかった。

これらの結果を考察すると市販品においてコーヒー， ココアなど苦味が主体となっているものに有意差がみら れなかったのは,これらの味が複雑でこの程度の添加で

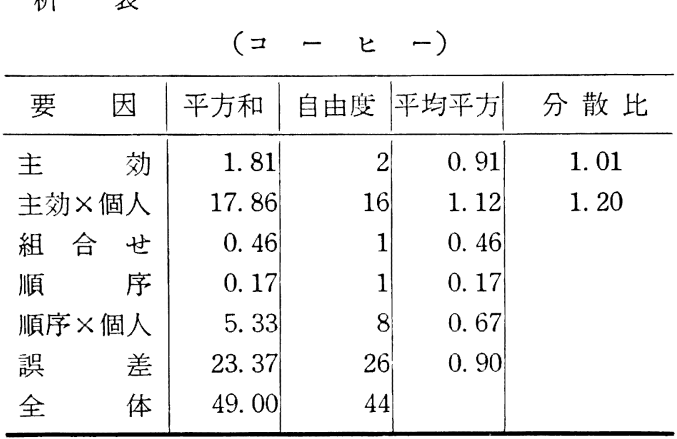

は味の差が明確にあらわれなかったのではないかと思わ れる。オレンジジュースの場合, その味は酸味と甘味の バランスが問題になる。 $\mathrm{PaA}-\mathrm{Ca}$ を添加することによっ て酸味が柔らげられるが，この变化は味わ5人によって 良くも悪くも感ぜられるわけであるが，全体的に， $\mathrm{PaA}-\mathrm{Ca}$ を添加することが悪影響を与えるものではない と考觉られる。ぶど5酒に拈いてて味に差がみられ，また 嗜好性が向上したのは, 使用した生ぶど5酒が酸味, 渋 味共比較的強いものであったためかもしれないが，市販 液状喏好食品のうちで一番差が認められた。

またサッカリンナトリウムに対して，PaA-Ca が良い 影響を与えることがわかり，従ってサッカリンナトリウ ムを添加した食品に $\mathrm{PaA}-\mathrm{Ca}$ を强化することは良い効 果がでるであろらと推察される。

以上の結果から $\mathrm{PaA}-\mathrm{Ca}$ を添加することによってて 苦味, 酸味, 涉味が弱くなり, 特に苦味が一舀影響を受 けることがわかったが，これらの変化が食品に与える影 響はマイナスになるものではなく，中にはかえって良い 効果を与えるものもあると思われる。

$$
\text { 要約 }
$$

食品に $\mathrm{PaA}$ - $\mathrm{Ca}$ を強化した場合の味の変化を調べる ため単一の呈味物質および市肘の液状㗪好食品に $\mathrm{PaA}$ Ca を添加し官能審査を実施した。

1）単一の呈味物質の場合, 苦味物質（カフェイン） は $\mathrm{PaA}-\mathrm{Ca}$ の添加によって味に変化がみられ苦味が弱 くなることがわかった。また人工甘味物質（サッカリン ナトリウム）に㧊いても苦味が弱くなるため, $\mathrm{PaA}-\mathrm{Ca}$ 
の添加が好ましい影響を及价すことがわかった。

2）它の他の呈味物質については，その変化は統部的 に有意なほど大きくなかった。

3）市販の液状嗼好食品に $\mathrm{PaA}$ - Ca を添加した場合 オレンジジュース, ら゙どう酒に変化がみられ, 添加区が 好ましいということがれかった。

終わりに陾乙終始ご指導を睗わった鳥山史郎所長に深

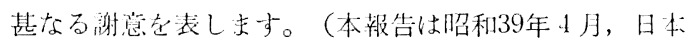

食品工業学会第11回大会で発表した）

$$
\text { 文献 }
$$

1) 山口直彦, 橫尾良夫, 小山吉人：栄養と食糧, 15, $323(1962)$

2) 大武由之：酪農科学の研究，12, A 155 (1963)

（裂知県食品工業試験所荣子課）

\section{人におけるビタミン $B_{6}$ 不足とトリプトファン代謝産物の尿中排泄}

トリブトファンの代謝に打よぼナ低ビタミン $\mathrm{B}_{6}$ の影 楒について6 6 名の罗子を被娩者とし，55日間実蹒した。 被験者方低 $\mathrm{B}_{6}$ 期閒に入る前の5 日間㧍上ず陚験期間中

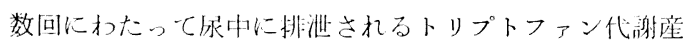
物圭測定した。低 $B_{6}$ の期間中汢企事に 1 日当たり 0.16 $\mathrm{mg}$ の $\mathrm{B}_{6}$ しか含まない上5にした。トリプトファン $2 \mathrm{~g}$

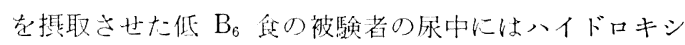
キヌレニン，キスレニン，キサンッレン酸，アセチルキ スレニンキマレニン酸などが著しく增してくる。これ らのトリプトファン代謝産物の排泄は被験者に 1 日 0.6 $\mathrm{mg}$ または $0.9 \mathrm{mg}$ のピリドキシンを与えると正常の䇦 曲にもどること死観察した。しかし. 6 名の5ち3 名は50 mg のピリドキシンを 3 日間連続投与するまでは奏験前 の状態にもどらなかった。このようなトリプトファン代 謝举物の排泄異常は以前デオキシピリドキシンを与えた 結核患者に扣いてて観察した例とよく似ている。これらの 現象はピリドキシンアンタゴニスト投与およびビタミン $\mathrm{B}_{6}$ 不足がトリプトフォン代謝における $\mathrm{B}_{6}$ 醭素の正常な はたらきを阻書することを示している。（表 2, 四7）

Vitamin $B_{6}$ Depletion in Man : Urinary Excretion of Tryptophan Metabolites.

by Yess, N, Price, J. M., Brown, R. R., Swan P. B., Linkswiler, H. : J. Nutrition, 84, (3), $229 \sim 236$ (1964) 